\title{
PREVALENSI ISOLAT MRSA PENGHASIL PANTON-VALENTINE LEUKOCIDIN PADA PASIEN ICU RUMAH SAKIT TERSIER
}

\author{
Linosefa $^{1}$, Delly Chipta Lestari ${ }^{2}$, Ardiana Kusumaningrum² ${ }^{2}$, Anis Karuniawati ${ }^{2}$, Andi Yasmon ${ }^{2}$
}

\begin{abstract}
Abstrak
Penilitian ini bertujuan untuk mengetahui prevalensi MRSA penghasil Panton-Valentine leukocidin (PVL) dan pola kepekaannya. Sampel penelitian adalah isolat MRSA dari 315 pasien Rumah Sakit Umum Pusat Nasional Cipto Mangunkusumo (RSUPNCM) selama tahun 2011 dan 2014, dengan melakukan identifikasi, uji kepekaan dan uji molekuler terhadap isolat tersebut. Penelitian ini menunjukkan sebanyak $59 \%$ dari koloni MRSA yang ditemukan masih sensitif terhadap antibiotik golongan selain $\beta$-laktam, sehingga masih dapat diduga sebagai community-associated MRSA (CA-MRSA). CA-MRSA sepertinya mulai ditransmisikan di fasilitas kesehatan. Uji molekuler terhadap isolat MRSA memberikan hasil 8,3\% isolat MRSA menghasilkan PVL. Berdasarkan tipe pola kepekaannya isolat MRSA penghasil PVL tersebut masih dapat digolongkan sebagai CA-MRSA. MRSA penghasil PVL ditemukan di RSUPNCM sebagai kolonisasi. Surveilan perlu dilakukan untuk memahami interaksi antara MRSA di komunitas dan rumah sakit, terutama untuk mengurangi transmisi di fasilitas kesehatan.
\end{abstract}

Kata Kunci: PVL, MRSA, CA-MRSA

\begin{abstract}
The aim of this study is to determine the prevalence of MRSA producing Panton-Valentine leukocidin/ PVL and their resistance patterns. Sample was MRSA isolate from Cipto Mangunkusumo Hospital during 2011 and 2014. The MRSA identification, antibiotic susceptibility testing and the molecular typing studies were performed. We have found $59 \%$ of colonization with MRSA isolates are susceptible to non-6-laktam agents, which may represent community-associated MRSA (CA-MRSA) strains. It seems that CA-MRSA strains have started to be transmitted in healthcare facilities. Molecular typing demonstrated that $8,3 \%$ of MRSA isolates had PVL positive. Based on its typical antimicrobial resistance pattern, MRSA PVL positive belongs to group CA-MRSA. MRSA strains that produced PVL were found to be colonizing in Cipto Mangunkusumo. Continued surveillance is, however, necessary to understand the interaction between MRSA in community and hospitals, especially to reduce the transmission in healthcare facilities.
\end{abstract}

Key words: PVL, MRSA, CA-MRSA

Afiliasi Penulis: 1. Bagian Mikrobiologi Fakultas Kedokteran Universitas Andalas 2. Fakultas Kedokteran Universitas Indonesia, Korespondensi: Linosefa, email: linosefa@yahoo.co.id, Telp/Hp:

$+6281374449708$ 


\section{PENDAHULUAN}

Staphylococcus aureus merupakan penyebab utama infeksi kulit, jaringan lunak dan tulang, serta merupakan salah satu penyebab bakteremia yang paling umum di rumah sakit. Sekitar $25 \%$ orang sehat membawa satu atau lebih strain secara asimptomatik dan umumnya infeksi yang terjadi secara endogen disebabkan oleh strain yang berkolonisasi di tubuh pasien. ${ }^{1}$ Nasal karrier $S$. aureus merupakan faktor risiko utama untuk terjadinya infeksi termasuk bakteremia. ${ }^{2}$

Sekitar 80\% dari semua strain S. aureus adalah resisten penisilin. ${ }^{3}$ CA-MRSA termasuk kolonisasi MRSA atau infeksi yang terjadi di komunitas atau saat masuk rumah sakit, tanpa memperhatikan apakah pasien memiliki riwayat kontak dengan pelayanan kesehatan. ${ }^{4}$ Berdasarkan laporan Laboratorium Mikrobiologi Klinik FKUI dari tahun 2009 sampai tahun 2012 terlihat peningkatan jumlah MRSA sebagai penyebab infeksi di RS. ${ }^{5-8}$ Pada tahun 2012 ditemukan MRSA sebagai penyebab infeksi di ruang ICU RSCM sebanyak $38 \%{ }^{8}$

Definisi epidemiologi dulunya dapat digunakan untuk membedakan strain CAMRSA dengan strain hospital acquired $S$. aureus (HA-MRSA). Strain CA-MRSA telah mulai ditransmisikan di fasilitas kesehatan, sehingga tidak sesuai dengan definisi epidemiologi. Secara genetik strain CA-MRSA berbeda dengan strain HA-MRSA. ${ }^{4}$ CA-MRSA dan HA-MRSA memiliki perbedaan signifikan dalam hal gejala klinis, pola resistensi antibiotik, dan pengobatan yang diperlukan. Karakteristik yang dimiliki CA-MRSA diantaranya adalah menghasilkan PantonValentine leukocidin (PVL) dan kepekaan terhadap antibiotik non- $\beta$ lactam. Adanya PVL meningkatkan virulensi $S$. aureus. Pendapat lain mengatakan ekspresi PVL oleh strain staphylococcal menimbulkan aktivitas sitotoksisitas yang kuat dan cepat terhadap neutrofil. ${ }^{10}$ Strain CA-MRSA yang memproduksi $P V L$ berhubungan dengan peningkatan risiko transmisi, komplikasi dan masa rawatan. ${ }^{1}$ Penelitian lain menyatakan bahwa strain yang berasal dari komunitas lebih virulen daripada yang berasal dari rumah sakit dan menyebabkan komplikasi evolusi yang cepat dan serius. Penelitian ini didesain untuk mengetahui prevalensi isolat MRSA penghasil PVL di Jakarta, khususnya di RSCM. Penelitian serupa belum pernah dikerjakan di Jakarta, sehingga hasil penelitian ini diharapkan dapat menjadi acuan dalam hal pengendalian infeksi dan terapi MRSA yang efektif di rumah sakit.

\section{METODE}

\section{a. Desain Penelitian}

Penelitian ini terdiri dari 2 tahap. Tahap 1 didesain secara retrospektif untuk mengidentifikasi PVL dari isolat tersimpan pasien perawatan intensif RSUPNCM tahun 2011. Untuk isolat tahun 2011, merupakan penelitian lanjutan dari penelitian sebelumnya oleh dr. Yulia Rosa, SpMK pada tahun 2011 yang berjudul Surveilans Multi Drug Resistant Organism di ICU FKUI/RSCM. Penelitian tahap 2 didesain secara prospektif untuk mengidentifikasi karakteristik PVL dari isolat pasien intensif RSUPNCM tahun 2014. Penelitian dilakukan di Laboratorium Mikrobiologi Klinik (LMK) Departemen Mikrobiologi Fakultas Kedokteran Universitas Indonesia dari Februari 2014 - Oktober 2014.

\section{b. Populasi}

Semua spesimen skrining dari pasien ICU dan HCU RSUPNCM tahun 2011 dan 2014 yang dikirim untuk pemeriksaan kultur di LMK FKUI. Sampel penelitian adalah 
semua isolat hasil skrining pasien ICU dan HCU RSUPNCM tahun 2011 dan 2014 yang mengindikasikan adanya bakteri MRSA, yaitu isolat Staphylococcus aureus yang resisten terhadap cefoxitin secara difusi cakram yang sesuai dengan rekomendasi CLSI.

\section{c. Cara Kerja}

1. Sampel

Isolat MRSA hasil skrining tahun 2011 tersimpan dalam agar stok dengan parafin cair. Kemudian ditumbuhkan pada manitol salt agar (MSA). Skrining MRSA 2014 dilakukan dengan pengambilan swab dari pasien ICU di inokulasikan ke manitol salt agar (MSA). Medium yang telah diinokulasi kemudian diinkubasi pada $35^{\circ} \mathrm{C}$ selama 18 24 jam. Koloni yang tumbuh menyerupai morfologi koloni Staphylococcus sp dilanjutkan dengan uji koagulasi (Staphaurex, remel) dan konfirmasi MRSA menggunakan identifikasi oleh sistem Vitek 2 (Biomérieux ${ }^{\circledR}$ ) dan uji PBP 2 latex agglutination.

\section{Uji Kepekaan}

Dilakukan uji kepekaan terhadap isolat yang telah diuji konfirmasi $S$. aureus menggunakan sistem vitek 2 (Biomérieux ${ }^{\circledR}$ ).

3. Deteksi PVL menggunakan duplek PCR

Strain kontrol positif MRSA yang digunakan dalam penelitian ini:

- PVL: 1269

- Nuc: $1269, \mathrm{P}-146, \mathrm{P}-63$

\section{Desain Primer}

Desain primer berdasarkan penelitian yang dilakukan McClure JA et al. pada tahun 2006 dan Zhang et al. pada tahun 2004 (tabel 1). ${ }^{9,10}$ Nuc gen digunakan sebagai kontrol internal yang bersifat spesies spesifik terhadap S. aureus.

\section{Isolasi DNA}

Isolasi DNA yang dilakukan pada penelitian ini menggunakan teknik pemanasan. Sus-pensi bakteri disiapkan dari 7-10 koloni bakteri Staphylococcus spp. berusia 18-24 jam dalam 500 ul destilated water (DW) pada tabung ependorf. Tabung disentri-fugasi pada $12.000 \mathrm{rpm}$ selama 2 menit, kemudian dibuang supernatannya. Sisa pellet ditambah dengan 250 ul DW kemu-dian dicampur kembali dan disentrifugasi pada $12.000 \mathrm{rpm}$ selama 2 menit, lalu di-buang supernatannya. Kemudian sisa pellet ditambahkan 100 ul DW lalu di vorteks dan dimasukkan ke dalam penangas air yang telah diatur suhunya pada $100^{\circ} \mathrm{C}$, selama 10 menit. Setelah itu tabung dikeluarkan dari penangas air, kemudian disentrifugasi $12.000 \mathrm{rpm}$, selama 10 menit. Supernatan diambil 100 ul dan dimasukkan ke dalam tabung eppendorf yang baru sebagai hasil isolasi DNA. Jika tidak langsung digunakan, hasil isolasi DNA dapat disimpan di freezer $-30^{\circ} \mathrm{C}$.

\section{Dupleks PCR}

Komposisi reaksi PCR duplek tercantum dalam tabel 2. Amplikon hasil PCR dipisah-kan pada gel agarose $2 \%$ dalam bufer Tris acetate EDTA (TAE) $1 \mathrm{x}$ menggunakan 100 bp ladder. Gel didokumentasikan menggu-nakan transiluminator ultraviolet (Biorad). Data yang diperoleh akan ditabulasi menggunakan program microsoft office excel 2010 yang disajikan dalam bentuk tabel dan narasi. 


\section{Persetujuan Etik}

Etik penelitian pada manusia dilakukan sesuai dengan pedoman yang digariskan oleh FKUI. Penelitian retrospektif telah lulus kaji etik dari Panitia Etik Fakultas Kedokteran Universitas Indonesia dengan surat nomor 530/PT02.FK/ETIK/2010. Penelitian prospektif telah lulus kaji etik dari Panitia Etik Fakultas Kedokteran Universitas Indonesia dengan surat nomor 150/H2.F1/ETIK/2014 dan addendum surat nomor 626/UN2.F1/ETIK/VIII/2014.

Tabel 1. Desain Primer untuk PCR Duplek

\begin{tabular}{|l|l|l|l|}
\hline PCR-1 & $\begin{array}{l}\text { Nama } \\
\text { primer }\end{array}$ & $\begin{array}{l}\text { Ukuran } \\
\text { (bp) }\end{array}$ & Sekuens (5'-3') \\
\hline PVL & $\begin{array}{l}\text { luk-PV-1 } \\
\text { luk-PV-2 }\end{array}$ & 433 & $\begin{array}{l}\text { ATCATTAGGTAAAATGTCTGGACATGATCCA } \\
\text { GCATCAASTGTATTGGATAGCAAAAGC }\end{array}$ \\
\hline nuc & $\begin{array}{l}\text { Nuc } 1 \\
\text { Nuc } 2\end{array}$ & 279 & $\begin{array}{l}\text { GCGATTGATGGTGATACGGTT } \\
\text { AGCCAAGCCTTGACGAACTAAAGC }\end{array}$ \\
\hline
\end{tabular}

Tabel 2. Komposisi Reaksi dan Kondisi Siklus PCR

\begin{tabular}{ll}
\hline & Dupleks PVL - nuc \\
\hline 10x PCR BuferHotStar & $2,5 \mu \mathrm{l}$ \\
$25 \mathrm{mM} \mathrm{MgCl} 2$ & $1 \mu \mathrm{l}$ \\
$10 \mu \mathrm{mol}(\mathrm{dNTP})$ mixture & $0,7 \mu \mathrm{l}$ \\
$5 \mathrm{x}$ Q Solution & $5 \mu \mathrm{l}$ \\
Primer mix luk-PV-1+luk-PV-2 $(10 \mu \mathrm{mol})$ & $0,6 \mu \mathrm{l}$ \\
Primer mix nuc 1 +nuc 2(10 $\mu \mathrm{mol})$ & $0,2 \mu \mathrm{l}$ \\
HotstarTaqDNA polymerase & $0,12 \mu \mathrm{l}$ \\
DNAse free water & $12,88 \mu \mathrm{l}$ \\
DNA sampel & $@ 2 \mu \mathrm{l}$ \\
Suhu dan siklus & $1 \mathrm{x}: 95^{\circ} \mathrm{C}$ selama 15 menit \\
& $10 \mathrm{x}: 94^{\circ} \mathrm{C} 30$ detik \\
& $57^{\circ} \mathrm{C} 45$ detik \\
& $72^{\circ} \mathrm{C} 1$ menit \\
& $25 \mathrm{x}: 94^{\circ} \mathrm{C} 30$ detik \\
& $50^{\circ} \mathrm{C} 45$ detik \\
& $72^{\circ} \mathrm{C} 1$ menit \\
& $1 \mathrm{x}: 72^{\circ} \mathrm{C}$ selama 5 menit \\
\hline
\end{tabular}

\section{HASIL DAN PEMBAHASAN}

Terdapat 115 stok MRSA yang didapatkan dari skrining MRSA pada pasien ICU RSUPN Cipto Mangunkusumo tahun 2011. Subkultur dan identifikasi ulang dilakukan pada isolat tersebut dan didapatkan 21 isolat adalah MRSA (19,1\%). Uji konfirmasi sifat resisten metisilin (deteksi gen mecA) dilakukan menggunakan uji aglutinasi latek PBP2 yang memiliki sensitifitas dan spesifisitas sama dengan deteksi PCR sebagai gold standard (100\% dan 100\%) dan didapatkan 1 isolat MRSA tambahan. ${ }^{11}$ Dari total 22 isolat, yang bisa diikutsertakan dalam penelitian hanya 19 isolat oleh karena tidak ditemukannya data rekam medik pasien yang merupakan asal isolat tersebut.

Skrining MRSA tahun 2014 terhadap 200 pasien perawatan intensif di RSUPN Cipto Mangunkusumo memberikan hasil positif MRSA sebanyak 5 pasien (2,5\%). Dari penelitian ini didapatkan angka kolonisasi MRSA pada pasien perawatan intensif di RSUPNCM sebesar 7,6 \%. Hasil yang serupa 
juga didapatkan pada penelitian di Taiwan tahun 2009 dan penelitian Warren tahun 2006 yang menemukan angka kejadian kolonisasi MRSA pada pasien ICU sekitar 14,9\% dan 8\%. ${ }^{12,13}$ Rendahnya angka kolonisasi MRSA mungkin saja disebabkan oleh program pengendalian infeksi telah dilaksanakan lebih baik dibandingkan tahun-tahun sebelumnya.

\section{Kepekaan MRSA terhadap Berbagai Golongan Antibiotik}

Tabel 3 menunjukkan tingkat resistensi MRSA terhadap kotrimoksazol masih cukup rendah (8,3\%). Hal sangat berbeda dengan penelitian di Nigeria yang menemukan angka resistensi terhadap kotrimoksazol sebesar 92,1\% ${ }^{14}$ Pada penelitian ini juga ditemukan semua isolat MRSA masih sensitif terhadap vankomisin dan linezolid. Penelitian di Riau tahun 2012 juga menemukan 100\% MRSA masih sensitif terhadap vankomisin. ${ }^{15} \mathrm{Hal}$ ini menunjukkan bahwa vankomisin masih menjadi pilihan terapi untuk MRSA, begitu juga dengan linezolid. Mekanisme resistensi S. aureus terhadap vankomisin (VRSA) belum begitu jelas, sebagian disebabkan oleh adanya gen vanA. ${ }^{16}$ Mekanisme resistensi linezolid disebabkan oleh gen $c f r$, mutasi binding site linezolid pada $23 \mathrm{~S}$ rNA, atau melalui protein ribosomal L3 L4 pada pusat translokasi peptida. Klinisi harus me-nyadari bahwa resistensi terhadap linezolid dan vankomisin dapat timbul mengikuti pemakaian antibiotik ini jangka panjang. Oleh karena itu diperlukan pemantauan berke-lanjutan pola kepekaan MRSA terhadap anti-biotik untuk untuk dijadikan dasar pemilihan terapi yang rasional. ${ }^{17}$

Secara mikrobiologi, untuk membedakan antara HA-MRSA dan CA-MRSA dapat menggunakan prediksi fenotipik berdasarkan pola resistensi antibiotiknya. Menurut CDC, HA-MRSA sering resisten terhadap banyak golongan antibiotik yang umum digunakan termasuk eritromisin, klindamisin, fluoroquinolon dan tetrasiklin, sementara CA-MRSA hanya resiten terhadap golongan $\beta$ laktam dan eritromisin, bisa juga terhadap fluoroquinolon. Pada penelitian ini jika dilihat dari pola kepekaan antibiotik menurut CDC tersebut ditemukan CA-MRSA $59 \%$ dan HAMRSA $41 \%$ (Tabel 4).

Tabel 3. Persentase Kepekaan MRSA terhadap Berbagai Golongan Antibiotik

\begin{tabular}{lcc}
\hline Nama Antibiotik & $\begin{array}{c}\text { Persentase Sensitif } \\
(\mathbf{\% )}\end{array}$ & Persentase Resisten (\%) \\
\hline Benzyl penisilin & 0 & 100 \\
Gentamisin & 66,7 & 33,3 \\
Siprofloksasin & 70,8 & 29,2 \\
Levofloksasin & 70,8 & 29,2 \\
Moksifloksasin & 70,8 & 29,2 \\
Eritromisin & 83,3 & 16,7 \\
Klindamisin & 70,8 & 29,2 \\
Quinupristin & 95,8 & 4,2 \\
Linezolid & 100 & 0 \\
Vankomisin & 100 & 0 \\
Tetrasiklin & 29,2 & 70,8 \\
Tigesiklin & 100 & 0 \\
Nitrofurantoin & 100 & 0 \\
Rifampisin & 75 & 25 \\
Kotrimoksazol & 91,7 & 8,3 \\
\hline
\end{tabular}


Tabel 4. Penggolongan MRSA berdasarkan Pola Kepekaan Antibiotik

\begin{tabular}{|c|c|c|c|c|c|c|c|}
\hline $\begin{array}{l}\text { No } \\
\text { Isolat }\end{array}$ & 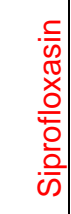 & 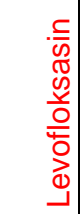 & 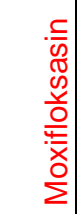 & 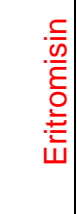 & 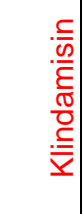 & 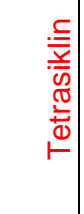 & Klasifikasi MRSA \\
\hline 1 & $\mathrm{R}$ & $\mathrm{R}$ & $\mathrm{R}$ & S & $S$ & $\mathrm{R}$ & HA-MRSA \\
\hline 2 & $\mathrm{R}$ & $\mathrm{R}$ & $\mathrm{R}$ & S & $\mathrm{S}$ & $\mathrm{R}$ & HA-MRSA \\
\hline 3 & S & S & S & S & $\mathrm{R}$ & $\mathrm{R}$ & HA-MRSA \\
\hline 5 & S & $\mathrm{S}$ & S & S & S & S & CA-MRSA \\
\hline 13 & $\mathrm{~s}$ & S & S & S & S & $\mathrm{R}$ & CA-MRSA \\
\hline 17 & S & S & s & s & S & $\mathrm{R}$ & CA-MRSA \\
\hline 21 & S & S & S & $\mathrm{R}$ & $\mathrm{R}$ & S & HA-MRSA \\
\hline 23 & S & S & S & S & S & S & CA-MRSA \\
\hline 24 & S & S & S & $\mathrm{S}$ & S & S & CA-MRSA \\
\hline 27 & S & $\mathrm{S}$ & S & $\mathrm{S}$ & S & $\mathrm{R}$ & CA-MRSA \\
\hline 33 & S & S & S & S & S & S & CA-MRSA \\
\hline 35 & S & S & s & S & $\mathrm{s}$ & $\mathrm{R}$ & CA-MRSA \\
\hline 37 & $\mathrm{~S}$ & $\mathrm{~S}$ & $\mathrm{~S}$ & $\mathrm{~S}$ & $\mathrm{~S}$ & $\mathrm{~S}$ & CA-MRSA \\
\hline 38 & S & $\mathrm{S}$ & $\mathrm{S}$ & S & $\mathrm{S}$ & S & CA-MRSA \\
\hline 43 & S & S & S & S & S & $\mathrm{R}$ & CA-MRSA \\
\hline 44 & $\mathrm{R}$ & $\mathrm{R}$ & $\mathrm{R}$ & $\mathrm{R}$ & $\mathrm{R}$ & $\mathrm{R}$ & HA-MRSA \\
\hline 45 & $\mathrm{R}$ & $\mathrm{R}$ & $\mathrm{R}$ & $\mathrm{R}$ & $\mathrm{R}$ & $\mathrm{R}$ & HA-MRSA \\
\hline 49 & S & $\mathrm{S}$ & S & S & S & $\mathrm{R}$ & CA-MRSA \\
\hline 50 & S & $\mathrm{S}$ & $\mathrm{S}$ & $\mathrm{S}$ & $\mathrm{S}$ & $\mathrm{R}$ & CA-MRSA \\
\hline 53 & $\mathrm{R}$ & $\mathrm{R}$ & $\mathrm{R}$ & $\mathrm{R}$ & $\mathrm{R}$ & $\mathrm{R}$ & HA-MRSA \\
\hline 54 & $\mathrm{R}$ & $\mathrm{R}$ & $\mathrm{R}$ & S & $\mathrm{S}$ & $\mathrm{R}$ & HA-MRSA \\
\hline 55 & $\mathrm{R}$ & $\mathrm{R}$ & $\mathrm{R}$ & s & S & $\mathrm{R}$ & HA-MRSA \\
\hline
\end{tabular}

Pembedaan HA/CA-MRSA hanya berdasarkan kriteria pola kepekaan (fenotipik) saja tidak bisa lagi dijadikan acuan. Berbagai penelitian menunjukkan adanya perkemba-ngan perubahan pola kepekaan CA-MRSA, menggantikan HAMRSA yang ditemukan di rumah sakit. Penelitian Popovich dkk menemukan dari semua MRSA penyebab bloodstream infection yang terjadi di rumah sakit, secara genotipik 24-49\% disebabkan oleh strain CAMRSA. ${ }^{18-20}$ Adanya PVL dan pola kepekaan antibiotik yang sesuai dengan kriteria CAMRSA bukanlah menjadi penanda pasti untuk deteksi CA-MRSA terutama jika strain CA-MRSA telah menyebar di RS dan komunitas. Namun jika ditemukan kolonisasi MRSA yang masih peka terhadap antibiotik selain $\beta$ laktam, masih dapat diduga sebagai CA-MRSA. ${ }^{21}$

\section{Uji Genotip}

Di antara 24 isolat MRSA, terdapat 2 isolat $(8,3 \%)$ yang hasil PCRnya menunjukkan pita sesuai dengan primer Luk-PV-1/2 yaitu isolat nomor 23 dan 43 (gambar 1 dan 2), sedangkan pita yang sesuai dengan primer nuc juga muncul di semua isolat (Staphylococcus aureus spesies). Angka ini lebih rendah dibandingkan hasil penelitian Hermos dkk tahun di ICU anak AS, dimana proporsi kolonisasi MRSA PVL positif sekitar 28,9\%. ${ }^{22}$ Penelitian Hanses dkk tahun 2010 di Jerman menemukan 4 dari 7 kolonisasi MRSA memiliki gen PVL. ${ }^{23}$ Begitu juga 
dengan hasil penelitian lain terhadap anakanak di Taiwan dan Kolumbia menemukan MRSA PVL positif dari kolonisasi sebanyak $17 \%$ dan $12,5 \%{ }^{24,25}$ Berbeda dengan hal tersebut Smith dkk tidak menemukan MRSA yang mem-bawa PVL dari 601 isolat kolonisasi MRSA. ${ }^{21}$ Jika dilihat dari pola kepekaan antibiotik kedua isolat MRSA PVL positif (tabel 5), maka masih dapat diduga isolat tersebut sebagai CA-MRSA oleh karena kedua isolat masih peka/sensitif terhadap antibiotika lain selain $\beta$ laktam. Seperti pada penelitian Haroe yang menemukan CAMRSA dengan PVL positif memiliki pola kepekaan antibiotik yang masih peka terhadap fluoroquinolon, gentamisin dan tobramisin dengan sensitifitas $77,8 \%$ dan PPV $72,4 \% .^{26}$

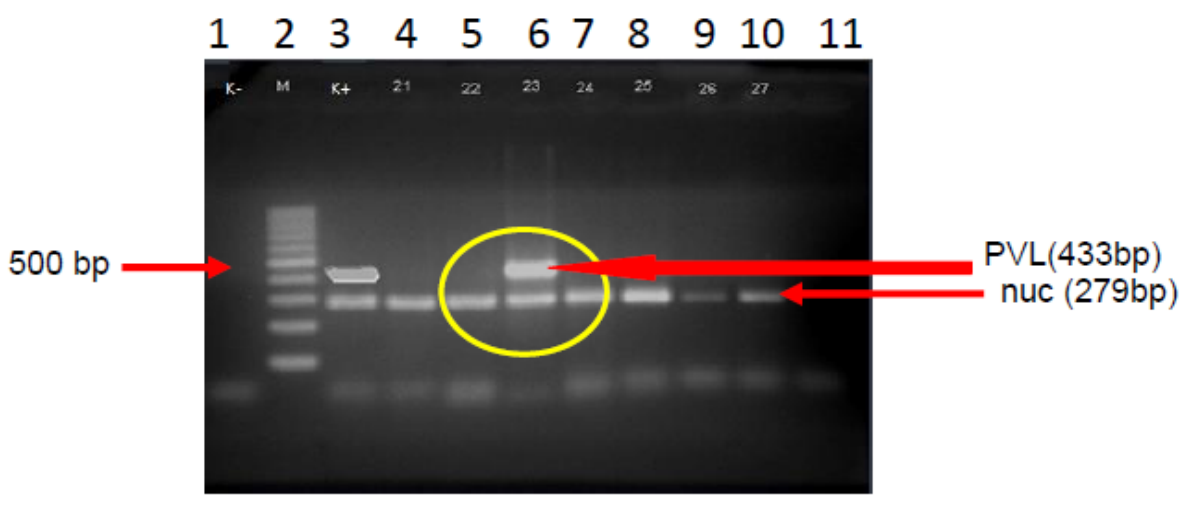

Gambar 1. Hasil PCR isolat 23. Lajur 1 merupakan kontrol negatif. Lajur 2 merupakan penanda (100 bp ladder). Lajur 3 merupakan kontrol positif. Lajur 4- 27 merupakan hasil PCR duplek isolat nomor 21-27.

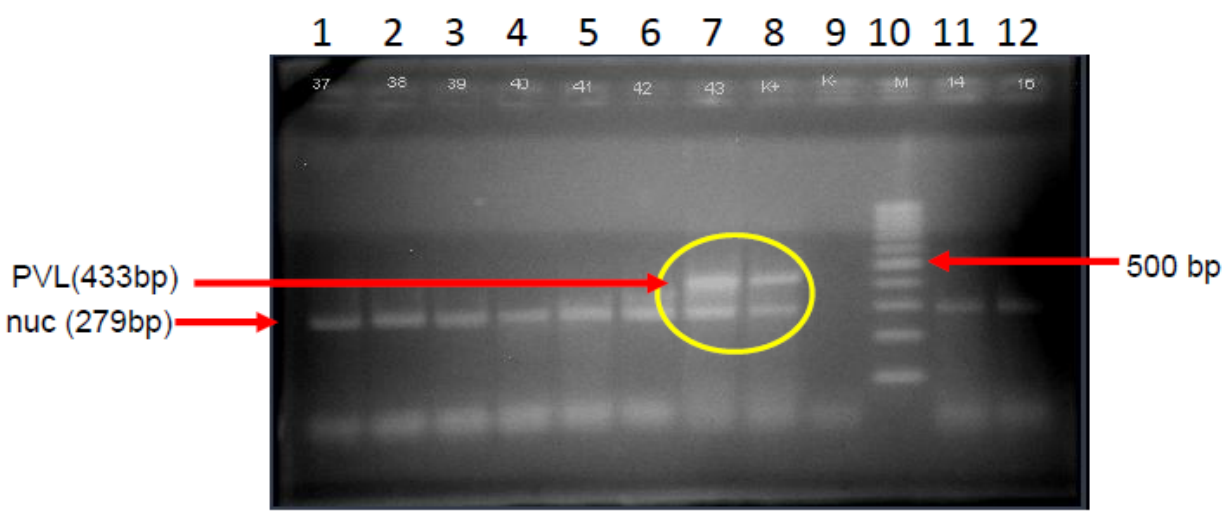

Gambar 2. Hasil PCR isolat 43. Lajur 1-7 merupakan hasil PCR duplek isolat nomor 27-43. Lajur 8 merupakan kontrol positif. Lajur 9 merupakan kontrol negatif. Lajur 10 merupakan penanda (100 bp ladder). Lajur 11. 12 merupakan hasil PCR duplek isolat no 14 dan 16

Tabel 5 Pola Kepekaan Isolat MRSA dengan PVL Positif

\begin{tabular}{|c|c|c|c|c|c|c|c|c|c|c|c|c|c|c|c|}
\hline $\begin{array}{c}\text { No } \\
\text { Isolat } \\
\text { MRSA } \\
\text { PVL (+) }\end{array}$ & 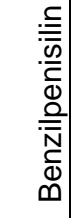 & 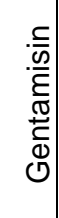 & 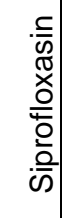 & 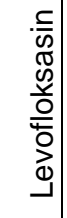 & 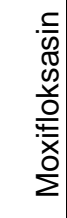 & 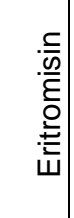 & 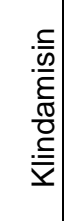 & 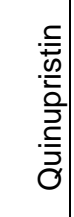 & 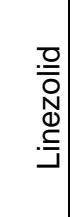 & 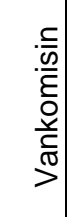 & 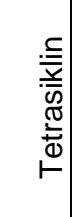 & 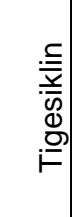 & 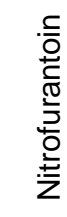 & 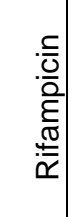 & 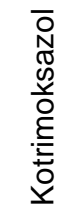 \\
\hline 23 & $\mathrm{R}$ & S & S & S & $S$ & S & S & S & S & S & $\mathrm{S}$ & $\mathrm{S}$ & $\mathrm{S}$ & $S$ & S \\
\hline 43 & $\mathrm{R}$ & S & S & S & $\mathrm{S}$ & $\mathrm{S}$ & S & $\mathrm{S}$ & S & S & $\mathrm{R}$ & $\mathrm{S}$ & $\mathrm{S}$ & $\mathrm{S}$ & $\mathrm{S}$ \\
\hline
\end{tabular}


Kombinasi PVL dan SCCmec tipe IV, dapat menjadi penanda genetik untuk CAMRSA. Gen PVL mengkode eksotoksin yang dihubungkan dengan infeksi kulit dan jaringan lunak seperti severe necrotizing pneumonia. Pada penelitian ini ditemukan 8,3\% PVL dari isolat MRSA. Umumnya publikasi prevalensi PVL pada CA-MRSA dihubungkan dengan infeksi klinis. Prevalensi PVL pada MRSA sebagai patogen pernah dilaporkan mencapai $30,5 \% .{ }^{27} \mathrm{Hal}$ ini mungkin memperlihatkan perbedaan virulen-si antara MRSA sebagai kolonisasi dengan MRSA sebagai penyebab infeksi.

Penelitian ini memiliki beberapa keterbatasan, antara lain memiliki jumlah sampel yang sedikit dan penelitian ini dilakukan pada satu tempat sehingga generalisasi data menjadi terbatas.

\section{SIMPULAN}

Sebanyak 8,3\% kolonisasi MRSA pada pasien perawatan intensif di RSUPN Cipto
Mangunkusumo tahun 2011 dan 2014 disebabkan oleh MRSA PVL positif. Isolat MRSA PVL positif yang ditemukan di RSUPN Cipto Mangunkusumo tahun 2011 dan 2014 dapat diduga sebagai CA-MRSA yang masih sensitif terhadap banyak golongan antibiotik (flouroquinolon, makrolid, aminoglikosida, klindamisin, linezolid, vankomisin, tigesiklin, rifampisin dan kotrimoksazol). Perlu dilakukan penelitian dengan jumlah sampel yang lebih besar dan tempat penelitian yang lebih luas tidak hanya mencakup pasien unit perawatan intensif, tetapi juga ruangan lain yang diperkirakan memiliki pasien dengan faktor risiko. Sebaiknya dilakukan surveilan berkelanjutan, yang diperlukan untuk mema-hami interaksi MRSA di komunitas dan di Rumah Sakit, terutama untuk mengurangi transmisinya.

\section{DUKUNGAN FINANSIAL}

Risbin Iptekdok 2014.

resistant Staphylococcus aureus: Formatex; 2007:766-74.

4. Otter JA, French GL. Review Communityassociated meticillin-resistant Staphylococcus aureus: the case for a genotypic definition. Journal of Hospital Infection 2012;81:143-8.

5. Staf Pengajar Departemen Mikrobiologi FKUI, PPDS Mikrobiologi Klinik FKUI. Hasil Uji Kepekaan Bakteri Terhadap Berbagai Antibiotik Tahun 2009. 2009:3.

6. Staf Pengajar Departemen Mikrobiologi FKUI, PPDS Mikrobiologi Klinik FKUI. Hasil Uji Kepekaan Mikroorganisme Terhadap Berbagai Antimikroba 2010; 2010.

7. Staf Pengajar Departemen Mikrobiologi FKUI, PPDS Mikrobiologi Klinik FKUI. Hasil Uji 
Kepekaan Bakteri Terhadap Berbagai Antibiotik Tahun 2012; 2012.

8. Seymour P, Golding J. Hospital Aqcuired and Community Acquired MRSA, Two Distinct Infection. Emergency Medicine 2009:36-41.

9. McClure JA, Conly JM, Lau V, et al. Novel Multiplex PCR Assay for Detection of the Staphylococcal Virulence Marker PantonValentine Leukocidin Genes and Simultaneous Discrimination of MethicillinSusceptible from -Resistant Staphylococci. Journal of Clinical Microbiology 2006;44:1141-4.

10. Zhang K, Sparling J, Chow BL, et al. New Quadriplex PCR Assay for Detection of Methicillin and Mupirocin Resistance and Simultaneous Discrimination of Staphylococcus aureus from CoagulaseNegative Staphylococci. Journal of Clinical Microbiology 2004;42:4947-55.

11. Sangeetha G, John J, Ranjith J. Comparison of Different Phenotypic Methods With PCR Detection of Mec A Gene for Detection of Methicilin Resistant Staphylococcus aureus (MRSA. International Journal of Pharmacy and Pharmaceutical Sciences 2012;4:Suppl 4.

12. Wang $\mathrm{J}-\mathrm{T}$, Liao $\mathrm{C}-\mathrm{H}$, Fang $\mathrm{C}-\mathrm{T}$, et al. incidence of and Risk Factors for Community-Associated Methicillin-Resistant Staphylococcus aureus Acquired Infection or Colonization in Intensive-Care-Unit Patients. journal Clinical Microbiology 2010;48:4439-44.

13. Warren D, Guth R, Coopersmith C, Merz L, Zack J, VJ F. Epidemiology of methicillinresistant Staphylococcus aureus colonization in a surgical intensive care unit. Infect Control Hosp Epidemiol 2006;27:1140-1.

14. Fayomi OD, Oyediran EIO, Adeyemo AT, Oyekale OT. Prevalence And Antibiotic Resistance Pattern Of Methicillin-Resistance Staphylococcus Aureus Among in-Patients at A Tertiary Health Facility in Ido-Ekiti, Nigeria. The Internet Journal of Laboratory Medicine 2009;4.

15. Annisa N, Anggraini D, Irawan D. Persentase dan Pola Resistensi Methicillin Resistant Staphylococcus Aureus dari Isolat Pasien yang Dirawat di Ruang Intensive Care Unit RSUD
Arifin Achmad Provinsi Riau Indonesia: Universitas Riau; 2012.

16. Thati V, T C, Shivannavar, Gaddad SM. Vancomycin resistance among methicillin resistant Staphylococcus aureus isolates from intensive care units of tertiary care hospitals in Hyderabad. Indian J Med Res 2011;134:704-8.

17. Gu B, Kelesidis T, Tsiodras S, Hindler J, Humphries RM. The emerging problem of linezolid-resistant Staphylococcus. Jour-nal of Antimicrobial Chemotherapy 2012.

18. Baddour MM. Public Health in the 21st Century : MRSA (Methicillin Resistant Staphylococcus aureus) Infections and Treatment. In. New York: Nova Science Publishers, Inc.. 2010.

19. Nadig S, Raju SR, Arakere G. Epidemic meticillin-resistant Staphylococcus aureus (EMRSA-15) variants detected in healthy and diseased individuals in India. Journal of Medical Microbiology 2010;59:815-21.

20. Popovich KJ, Weinstein RA, Hota B. Are Community-Associated Methicillin-Resis-tant Staphylococcus aureus (MRSA) Strains Replacing Traditional Nosocomial MRSA Strains? Clinical Infectious Diseases 2008;46:787-94.

21. Smith CS, Parnell P, Hodgson G, et al. Are methicillin-resistant Staphylococcus aureus that produce Panton-Valentine leucocidin (PVL) found among residents of care homes? Journal of Antimicrobial Chemotherapy 2008.

22. Hermost CR, Sandora J, Williams LE, Mosammaparast N, McAdam AJ. Cha-nging epidemiology of methicillin-resistant Staphylococcus aureus colonization in paediatric intensive-care units. Epide-miology Infection Journal 2013;141:1983-92.

23. Hanses F, Huetz $T$, Reischl U, Ehrenstein BP, Linde $\mathrm{H}-\mathrm{J}$, Salzberger B. Lack of evidence for persistent nasal colonization with community-acquired methicillin-resistant Staphylococcus aureus in a central European cohort. Clinical Microbiology and Infection 2011;17:466-8. 
24. Lo $\mathrm{W}-\mathrm{T}$, Lin $\mathrm{W}-\mathrm{J}$, Tseng $\mathrm{M}-\mathrm{H}$, Wang $\mathrm{S}-\mathrm{R}$, Chu $M-L$, Wang C-C. Communityacquired Methicillin-resistant Staphylococcus aureus in Children, Taiwan. Emerging Infectious Diseases 2006;12:1267-70.

25. Rebollo-Pérez J, Ordoñez-Tapia C, HerazoHerazo C, Reyes-Ramos N. Nasal carriage of Panton Valentine leukocidin-positive methicillin-resistant Staphylococcus aureus in healthy preschool children. salud Publica 2011;13:824-32,.

26. Gbaguidi-Haore H, Thouverez M, Couetdic Gr, Cholley P, Talon D, Bertrand X. Usefulness of antimicrobial resistance pattern for detecting PVL- or TSST-1-producing meticillinresistant Staphylococcus aureus in a French university hospital. Journal of Medical Microbiology 2009;58:1337-42.

27. Dash N, Panigrahi D, Zarouni MA, Yassin F, AlShamsi M. Incidence of community-acquired methicillin-resistant Staphylococcus aureus carrying Pantone-Valentine leucocidin gene at a referral hospital in United Arab Emirates. APMIS 2014;122:341-6. 